Kosiba, A., and Loewe, F. Meteorological observations in the Tasersiaq area, southwest Greenland, during summer, 1963. Ohio State University. Institute of Polar Studies. Report No. i 1, 1964, [vi, 59] p. [General account of meteorological observations and particular study of wind. Influence on snow and ice accumulation on Sukkertoppen ice cap discussed.]

MCVenil, G. E. Wind and temperature profiles near the ground in stable stratification. Quarterly Journal of the Royal Meteorological Society, Vol. 9o, No. 384, 1964, p. $136-46$. [Antarctic and U.S.A. data compared. Surface stress and heat flux deduced.]

SNOW

[Austria: Sngw.] Der Schnee in Österreich im Zeitraum r9or-1950. Beiträge zur Hydrographie Österreichs, Ht. 34, I 962, i 74 p., maps.

Bergen, J. D., and Swanson, R. H. Evaporation from a winter snow cover in the Rocky Mountain forest zone. Proceedings of the Western Snow Conference, 32nd annual meeting, 1964, [pub.] 1964, p. 52-57. [Quantitative
results.]

Coulianos, C.-C., and Johnels, A. G. Note on the subnivean environment of small mammals. Arkiv för Zoologi, Ser. 2 , Bd. ${ }_{15}$, No. 24,1962 , p. 363-70. [Observations on biological importance of snow cover from central Sweden.]

[France: Institutions.] Institut Français pour l'Étude de la Neige au Parc national de la Vanoise. Les Alpes. Revue du Club Alpin Suisse, 40e An., 3e Trimestre, 1964, p. 74-75. [Institute for study of snow in all aspects in course of construction in Parc national de la Vanoise.]

Herman, J. R. On the electrical properties of blowing snow. Annales de Géophysique, Tom. 20, No. 3, 1964, p. 235-4I. [Deduced from radio noise.]

Judson, A. Relative importance of weather factors creating slab avalanches in Colorado. Proceedings of the Western Snow Conference, 32 nd annual meeting, 1964, [pub.] 1964, p. 6o-67.

Onufriyenko, L. G. Losses of snowmelt on slopes. Soviet Hydrology. Selected Papers, 1964, No. 1, p. 55-6 1. [Observations on effect of slope on run-off.]

Power, B. A., and others. Snow crystal forms and riming effects as related to snowfall density and general storm conditions, [by] B. A. Power, P. W. Summers [and] J. D'Avignon. Fournal of the Atmospheric Sciences, Vol. 21, No. 3, 1964 , p. 300-05. [Relationship found between new-snow density and crystal form.]

Utringer, H. Die Dauer der Schneedecke in Zürich. Archiv für Meteorologie, Geophysik und Bioklimatologie, Ser. B, Bd. 12, Ht. 3-4, 1963, p. 404-21. [Number of days with snow cover at Zürich, Switzerland, since winter 1880-81.]

\title{
DUPLICATE PAPERS
}

A new list of duplicate papers in the Library of the Society, available for distribution to members, can now be obtained from Dr. G. Seligman, Little Dane, Biddenden, Ashford, Kent, England. Members are requested to apply for this as early as possible. 